\title{
SOLAR RADIATION AFFECTS GRAPEVINE SUSCEPTIBILITY TO Plasmopara Viticola
}

\author{
Anna Dalla Marta ${ }^{1}$; Valentina Di Stefano ${ }^{1}$; Zoran G. Cerovic²; Giovanni Agati ${ }^{3}$; Simone \\ Orlandini $^{1 *}$ \\ ${ }^{1}$ University of Florence - Dept. of Agronomy and Land Management, Piazzale delle Cascine 18 - 50144 - \\ Florence - Italy. \\ 'Université Paris-Sud - Equipe de Biospectroscopie Végétale, Laboratoire d'Ecologie Systématique et Evolution, \\ CNRS UMR 8079, Bât. 362 - 91405 - Orsay Cedex - France. \\ National Research Council - Institute of Applied Physics "Nello Carrara", Florence, Via Madonna del Piano \\ 10, 50019 - Sesto Fiorentino, Florence - Italy. \\ *Corresponding author <simone.orlandini@unifi.it>
}

\begin{abstract}
Solar radiation plays an important role in the development of some fungal diseases due to its direct action on the microorganisms and also its indirect effect on the production of specific plant compounds. This experiment examined the effect of two light environments $(100 \%$ and $35 \%$ of full strength) on the polyphenolic content of grapevine leaves and quantified their relation to resistance to downy mildew (Plasmopara viticola). Leaf epidermal polyphenolic contents were non-destructively measured during the growing season 2006 using the Dualex chlorophyll fluorescence-based portable leaf-clip. The experimental design consisted of six parcels of 30 vines and measurements were performed on the 12 central vines. The leaves were inoculated with a sporangia suspension containing 50,000 sporangia of $P$. viticola per $\mathrm{mL}$ and the disease severity was assessed after the appearance of symptoms. Leaves maintained at $100 \%$ sun had high polyphenolic content and significantly lower disease severity compared to leaves under shading nets. These results indicate an inverse relationship between produced
\end{abstract} polyphenolics and downy mildew severity.

Key words: Ultra-violet radiation, photosynthetic active radiation, polyphenolics, downy mildew, resistance

\section{RADIAÇÃO SOLAR E SUSCEPTIBILIDADE DA VIDEIRA À Plasmopara Viticola}

RESUMO: A radiação solar exerce papel importante no desenvolvimento de algumas doenças fúngicas, devido à sua ação direta sobre os microorganismos e também devido ao seu efeito indireto sobre a produção de compostos específicos nas plantas. Este experimento examinou o efeito de dois ambientes de luz (100\% e 35\% da intensidade máxima) sobre o conteúdo de polifenóis nas folhas da videira e quantificou sua relação com a resistência ao míldio (Plasmopara viticola). As concentrações de polifenóis na epiderme das folhas foram quantificadas de forma não destrutiva, durante a estação de crescimento de 2006, usando o equipamento portátil Dualex, baseado na fluorescência da clorofila. O delineamento experimental consistiu de seis parcelas de 30 videiras e as medidas foram feitas nas 12 plantas centrais. As folhas foram inoculadas com uma suspensão de esporângios com 50.000 esporos de $P$. viticola por $\mathrm{mL}$ e a intensidade da doença foi avaliada depois do aparecimento dos primeiros sintomas. As folhas das plantas mantidas à plena luz solar apresentaram alta concentração de polifenóis e severidade da doença significativamente menor do que as folhas das plantas mantidas sob a tela de sombreamento. Estes resultados indicam uma relação inversa entre os polifenóis produzidos pelas folhas da videira e a severidade do míldio.

Palavras-chave: Radiação ultra-violeta, radiação fotossinteticamente ativa, polifenóis, míldio, resistência

\section{INTRODUCTION}

Solar radiation plays an important role on meteorological elements, including air temperature, relative humidity and leaf wetness. In turn, these elements can all have a direct effect on microorganisms, thus influencing their disease cycle and infection intensity (Matta, 1996; Agrios, 1998; Orlandini, 1998). Moreover solar radiation, and in particular its ultraviolet (UV) component, can increase the probability of infections 
by inducing sporulation during the day (Ensminger, 1993). Conversely, UV can kill fungal spores with an insufficient supply of protective antioxidant pigments. At the same time, the quantity and quality of solar radiation reaching the plant canopies can also have a complex set of indirect effects on the susceptibility of plants to some diseases.

The intensity and spectral composition of leaf irradiance greatly affect the accumulation of phenolic compounds in leaves, which is of primary importance in response to a pathogen attack (Dai et al., 1995a; Dixon \& Paiva, 1995; Rozema et al., 1997). In fact, the relation between the presence of phenolic phytoalexins, anthocyanins and other phenolic compounds and the resistance to some important pathogens, such as Plasmopara viticola and Botrytis cinerea is well documented (Dai et al., 1995b; Jersch et al., 1989; Petez \& Pont, 1992; Kortekamp, 2006; Bonomelli et al., 2004).

Recently, a low susceptibility to powdery mildew (Erysiphe necator) in grapevines was related to high constitutive leaf phenolic compounds, mainly flavonol glycosides (Keller et al. 2003). New indications of the role of flavonoid metabolism are emerging in resistance to downy mildew in other pathosystems, such as the monocot Pennisetum glaucum against Sclerospora graminicola (Geetha et al., 2005; Niranjan Raj et al., 2006). There was an increase in infection caused by different pathogens with several species under shade environments (Pennypacker, 2000; Roberts \& Paul, 2006). Interestingly, there was also evidence of an inverse correlation between infection severity and the intensity of pre-inoculation light treatments (Shafia et al., 2001). The relation between solar radiation and plant susceptibility to pathogen attacks is particularly important for plants, such as grapevines (Vitis vinifera) where different management techniques may affect the quality and quantity of light penetrating the canopy. These practices, included pruning, trellis systems, leaf or shoot removal, reduced use of nitrogen fertilizers, reduced spacing between plants and rows, are all factors that affect the canopy architecture and, in turn, its interaction with solar radiation.

In this study an experimental vineyard was maintained under two solar radiation regimes in order to induce the production of different polyphenolic compounds in leaves, particularly EPidermal polyPhenols (EPhen) which are representative of total leaf phenols (Kolb \& Pfündel, 2005; Barthod et al., 2007), and to analyse their response to downy mildew inoculations. In addition, the advent of non-destructive means of following leaf flavonoids in vivo has allowed for overcoming the inherent variability of leafto-leaf flavonoid content and of following the same leaf throughout the season. Due to the novelty of the grapevine technique, destructive flavonoid analysis by HPLC was performed to verify the specificity and robustness of the non-destructive method.

\section{MATERIAL AND METHODS}

The experiment was carried out (May-August 2006) on the experimental Mondeggi Lappeggi farm located in the Chianti region of Tuscany (Central Italy) $\left(43^{\circ} 47^{\prime} \mathrm{N}, 11^{\circ} 35^{\prime} \mathrm{E}\right)$. The site elevation was $180 \mathrm{~m}$ above sea level and the slope about $16 \%$. In the experimental vineyard (Paretaio) grapevines of Sangiovese cultivar were cordon trained and spur pruned (4-5 spurs with two buds per vine), rows were north-south oriented and the spacing was $1 \mathrm{~m}$ along the rows and $3 \mathrm{~m}$ between the rows. The canopy was trained in a single curtain between 90 and $210 \mathrm{~cm}$ above ground level.

The vineyard was divided into six $18 \times 5-\mathrm{m}$ plots, three of which were covered with plastic shading nets mounted $3 \mathrm{~m}$ above the ground on a metallic tunnel structure in order to ensure sufficient canopy ventilation. The remaining three plots were left in full sun conditions as a control. Each parcel included about 30 vines and measurements were taken on the 12 central vines. The shading nets were mounted on May 12 when EPhen started accumulating in the leaves, then after the second half of June they moved to the other parts of the plant, probably the berries.

The fraction of incident radiation that passes through the shading nets (transmittance) was measured using a double monochromator spectroradiometer (model SR9910-PC, Macam Photometric Ltd, Livingstone, Scotland). From May 12 until August 1 the air and leaf temperature, relative humidity, and solar radiation were monitored outside and under the tunnels in order to control the potential effects of the shading nets on the microclimate. Air temperature and relative humidity were measured at ten-minute intervals by Hobo thermo-hygrometric microstations (Onset Computer Corporation; thermistor resolution of $0.02^{\circ} \mathrm{C}$ and precision of $0.1^{\circ} \mathrm{C}$ ). Leaf temperature was measured hourly using a handheld infrared thermometer (Everest Interscience Inc., model 100.3ZL) on both sides of the rows. UV-A (400-315 nm), UV-B (315-280 nm), PAR and global radiation were measured by the double monochromator spectroradiometer $(100 \mathrm{~mm}$ focal length, $200-800 \mathrm{~nm}$ spectral range, $0.5 \mathrm{~nm}$ wavelength accuracy) equipped with a diffuser connected to the input slit of the monochromator by a 1.8-m long optical fibre. The diffused error associated with the cosine response was less than $3 \%$ for a zenith angle up to $70^{\circ}$. All the measurements were taken in both sunexposed and shaded sites. 
Epidermal polyphenols (EPhen) were optically estimated in situ using the portable leaf-clip device Dualex (Force-A, Orsay, France) that determines the epidermal absorbance in the UV-A, mainly due to flavonoids, by comparing the chlorophyll fluorescence (ChlF) signals at two different excitation wavelengths (375 and $650 \mathrm{~nm}$ ) (Goulas et al., 2004; Cartelat et al., 2005). The EPhen content was expressed in absorbance units as indicated by the Dualex. To limit EPhen variability due to leaf age, only two fully expanded leaves positioned under their relative bunches (the fifth and the sixth leaf from the base of the vine shoot) were selected for the measurements. Adaxial (AD) and abaxial (AB) leaves were measured separately because they proved to be vastly different from each other. In particular, two $\mathrm{AD}$ and two $\mathrm{AB}$ measurements were recorded in sequence from the middle part of the leaf, avoiding the main veins. EPhen content of single leaves was defined as the sum of the $\mathrm{AD}$ and $\mathrm{AB}$ values, and these were the mean of the two measurements taken from each side. For the calibration, thirty leaves (shaded and sun-exposed) with total Dualex units in the 1.1-3.3 range were collected on June 29, 2006, measured again ( $\mathrm{AD}$ and $\mathrm{AB})$ in the lab and then 4 disks (12 $\mathrm{mm}$ in diameter) per measured area were punched off and frozen in liquid $\mathrm{N}$, for successive extraction and HPLC analysis (Agati et al., 2008).

On July 20, 72 leaves (36 for each radiation environment) located in the middle part of the shoots, between the $15^{\text {th }}$ and $20^{\text {th }}$ node from the base, were inoculated (20 July) by spraying their surfaces with a sporangial suspension of $P$. viticola obtained in laboratory and then enclosed in polyethylene bags for 12 $\mathrm{h}$ overnight. The sporangia concentration, determined by a Burker counting chamber, was $1.6 \times 10^{5}$ sporangia $\mathrm{mL}^{-1}$.

The severity of $P$. viticola infections was determined via a visual evaluation of the leaf area of interest for the typical symptoms (oilspots, mosaic and necrosis) 18 days after inoculation, when the oil spots reached the largest infected area before sporulation. The severity was expressed as percentage of infected area in relation to the total leaf area.

The results of the measurements were subjected to a one-way analysis of variance to compare the mean values for the two light regimes. Curve fitting of experimental data and calculation of the $95 \%$ confidence limits were also performed.

\section{RESULTS AND DISCUSSION}

The differences in air temperature and relative humidity were calculated between the sites in full sun and under shading nets. The temperature differences varied from $-1.27^{\circ} \mathrm{C}$ to $0.80^{\circ} \mathrm{C}$, with a mean value of $-0.23^{\circ} \mathrm{C}$ for the period from May 18 to June 4 (Figure 1). The variation range of the relative humidity was between $-8.13 \%$ and $8.23 \%$, with a mean value of $0.55 \%$ (Figure 2). The differences in air temperature and relative humidity observed between the sun-exposed and shaded sites were not significant $(p>0.5)$.

The mean difference between the sun and shade leaf temperatures (July 11) for the eastern and western sides of the vine rows was $1.21^{\circ} \mathrm{C}$, with the highest differences of $1.65^{\circ} \mathrm{C}$ and $1.40^{\circ} \mathrm{C}$ measured early in the morning (7h00 a.m.) and late in the afternoon (5h00 p.m.) respectively, with a minimum of $0.88^{\circ} \mathrm{C}$ at $1 \mathrm{~h} 00$ p.m. (Figure 3 ). In relation to other microclimatic variables, the differences observed were not significant $(p>0.5)$.

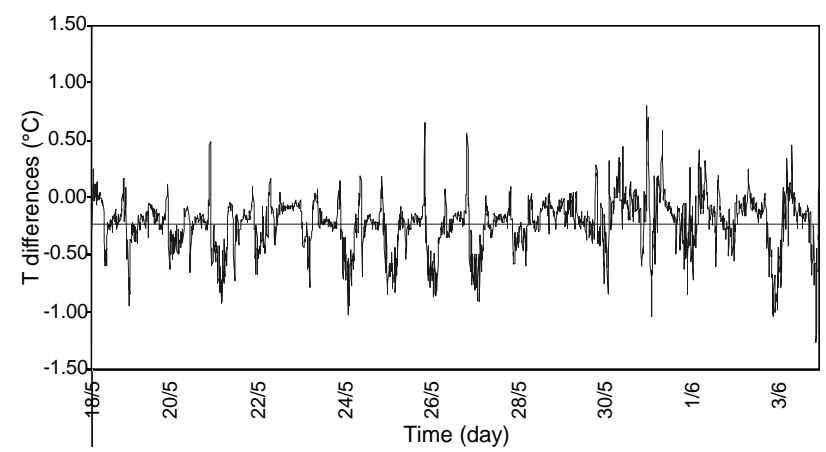

Figure 1 - Differences in air temperatures $\left({ }^{\circ} \mathrm{C}\right)$ between full sun and shaded sites.

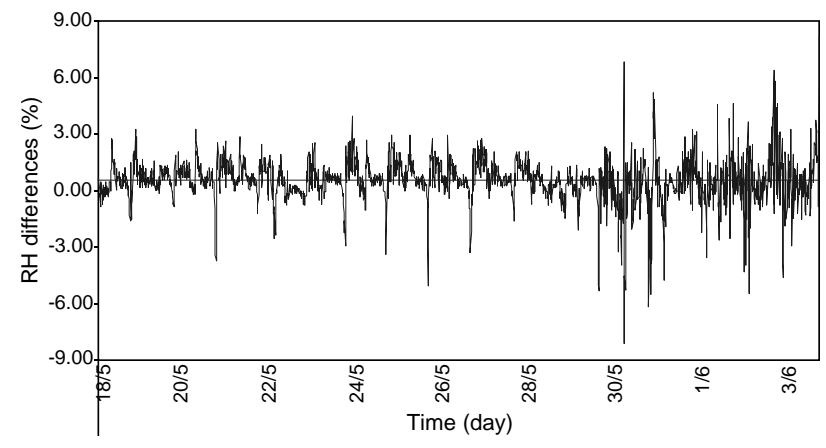

Figure 2 - Differences in relative humidity (\%) between full sun and shaded sites.

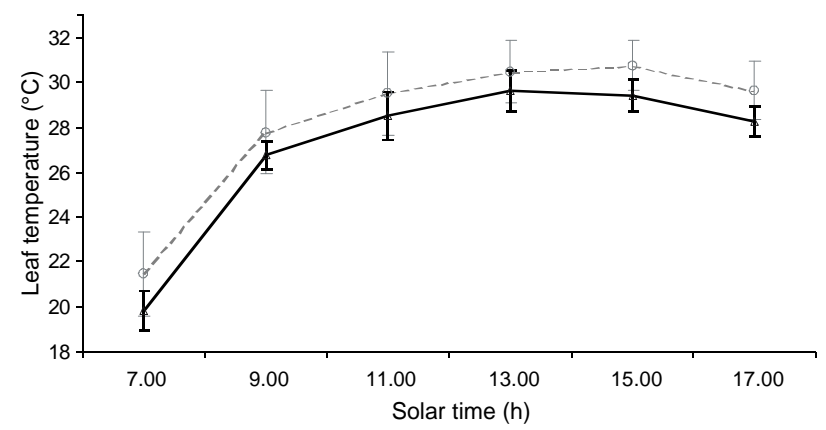

Figure 3 - Leaf temperatures $\left({ }^{\circ} \mathrm{C}\right)$ of vines exposed to sun (dotted line) and under the tunnels (continuous line). Bars represent the standard deviation. 
Spectroradiometric measurements (July 11) showed that the shading nets intercept about $65 \%$ of PAR and UV wavelengths. Since the percentage of radiation filtered under the tunnels was constant during the day at different solar elevations and azimuth (Figures $4 \mathrm{a}, 4 \mathrm{~b}$ ), this percentage was considered to be constant throughout the entire experimental period.

The non-destructive optical measurement of leaf epidermal polyphenols performed by the Dualex was calibrated by using the HPLC analysis of extracts from the same leaf area. The HPLC analysis of leaf polyphenols revealed the presence of the following compounds: quercetin-3-O-glucuronide, quercetin-3O-glucoside, rutin, kaempferol-3-O-glucuronide, kaempferol-3-O-glucoside, and the tartaric esters of caffeic, p-coumaric and ferulic acid (caftaric, coutaric and fertaric acids) (Agati et al., 2008).

Leaf polyphenols measured during the experimental period had a variation over time $(p<0.0005)$ both in sunny and shaded conditions. The influence of solar radiation was clearly evident in both light regimes as a result of the constant increase of EPhen content in the first part of the season, which reached a maximum on June 21 when solar irradiance was highest (Figure 5). The EPphen then decreased, probably due to catabolism, polymerisation or translocation of these compounds from leaves to other plant organs. However, for vines exposed to full radiation the tendency of the EPhen to increase could also be noticed at the end of the season (Figure 5).

The effect of solar radiation was also highlighted by the difference on leaf EPhen content mea-
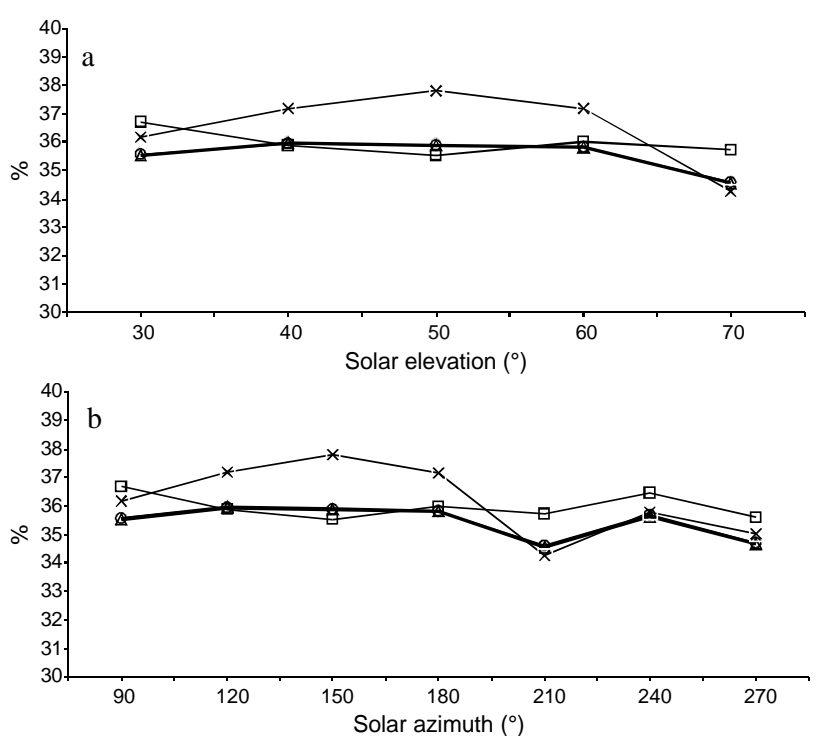

Figure 4 - Percentage of horizontal incident radiation filtered under the shading nets at different solar elevations (a) and azimuth (b). The components of UV (circles), UVB (squares), UVA (triangles) and PAR (cross) radiation are reported. sured in full sun and in shaded plots (Figure 5). In accordance with previous studies on polyphenol synthesis induced by radiation (Kolb et al., 2001), the difference between the two conditions increased from the beginning (0.79 Dualex units on May 23) to the end of the season (1.25 Dualex units on August 1) when EPhen content in leaves exposed to full sun was about $70 \%$ higher compared to the leaves of shaded vines.

The EPhen content of leaves before inoculation was homogeneous, and it was found to be different $(p<0.0005)$ in leaves exposed to the sun $(2.44$ $\pm 0.29)$ compared to leaves under the shading nets $(1.37 \pm 0.21)$.

The analysis of downy mildew severity indicated an inverse relation between EPhen content and the percentage of infection (Figure 6). In fact, the infected leaf area was more than three times higher in shaded $(15.7 \pm 8.4)$ versus sun exposed leaves $(5.0 \pm$ 3.6) $(p<0.0005)$. The relation is also confirmed by averaging EPhen contents of leaves divided into classes of disease severity which had an increase of the level of infected relative leaf area corresponding to a decrease in polyphenolic content (Figure 7).

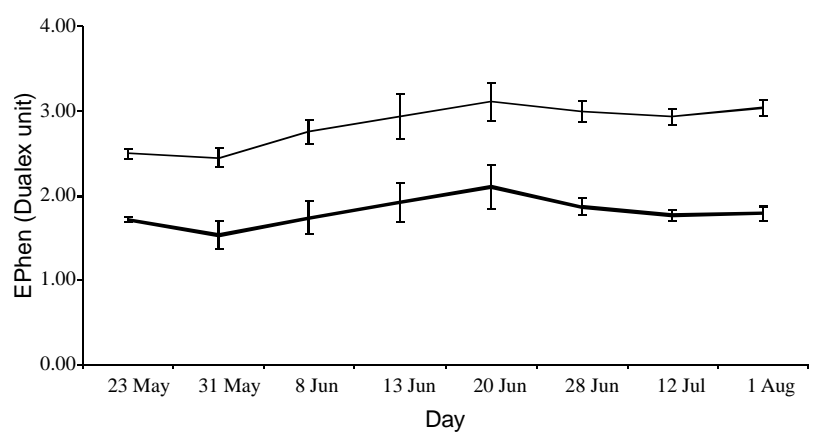

Figure 5 - Trend of epidermal polyphenols (Dualex units) measured during the season in full sun (fine line) and in shaded (bold line) leaves. Bars represent standard deviation.

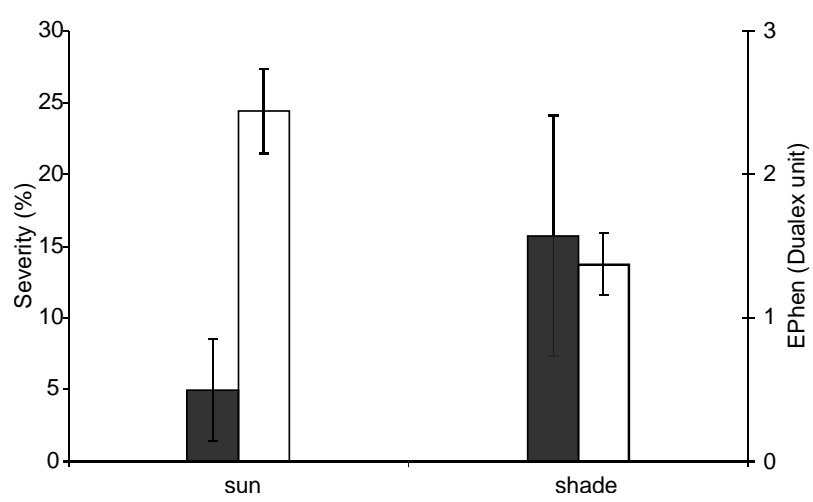

Figure 6 - Content of epidermal polyphenols (Dualex units) (white columns) and downy mildew severity (\%) (black columns) measured in full sun and under the tunnels. Bars represent standard deviation. 
The analysis of agrometeorological variables of air and leaf temperature and relative humidity showed that no significant differences in microclimate were induced by the presence of shading nets, so that the differences measured under and outside the tunnels were unable to affect the development of downy mildew. At the same time, the analysis of spectroradiometric data demonstrated that shading nets affected the quantity of solar radiation reaching the plants while its quality remained unchanged, as shown by the ratio between UV and visible radiation (Figure 8). Therefore, potential effects on disease development should be attributed to light intensity that affects the epidermal polyphenolic content of vine leaves. In fact, defence mechanisms such as the production of polyphenolic compounds, are known to contribute towards protecting grapevines against downy mildew (Hammerschmidt, 1999), and could explain the different development of the disease in inoculated sun-exposed and shaded leaves.

\section{CONCLUSIONS}

Solar radiation plays an important role in the production of phenolic compounds which affect the degree of infection by $P$. viticola. In fact the production of polyphenolic compounds, directly linked to the intensity of solar radiation, have a significant influence on the process responsible for greater resistance to downy mildew in sun-exposed versus shaded grapevine leaves.

The knowledge of the light regime in the vineyard and consequent vineyard management can be considered a starting point for adopting the best crop protection strategies. Row orientation, plant spacing, and canopy architecture (pruning techniques, shoot or leaves removal etc.) are related to the quantity of solar radiation intercepted by leaves and can be exploited in order to obtain a natural enhancement of constitutive defences against fungal diseases. Moreover, the possibility to measure leaf flavonoids by the use of a non-destructive device can represent a simple method to predict susceptibility of grapevine to downy mildew, with the aim to reduce and optimise chemical treatments.

\section{ACKNOWLEDGMENTS}

The authors wish to thank the Provincia di Firenze for making the Chianti vineyard at the Mondeggi-Lappeggi farm available for this research. The authors are also grateful to Daniele Grifoni and Francesco Sabatini (IBIMET-CNR) for performing the spectroradiometric measurements.

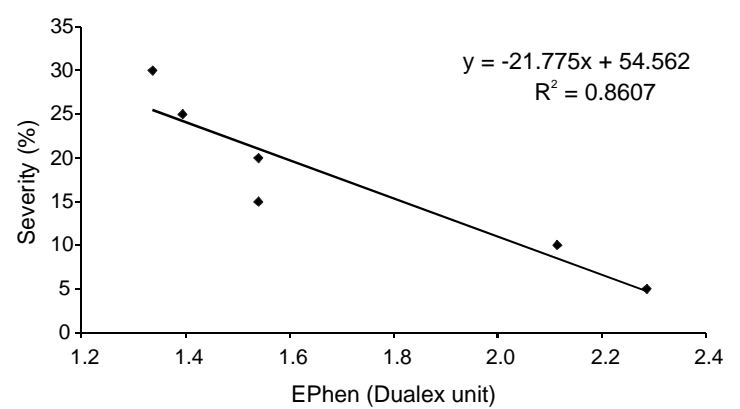

Figure 7 - Relation between the averaged content of epidermal polyphenols (Dualex units) and the severity (\%) of grapevine downy mildew for leaves grouped into different severity classes. The trend line is illustrated and the determination coefficient $\mathrm{R}^{2}$ is reported.

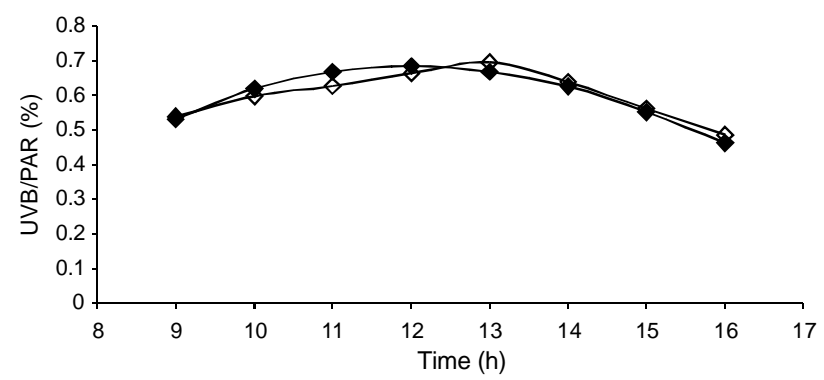

Figure 8 - Trends of UVB/PAR ratio measured under (white squares) and outside the tunnels (black squares) during the day.

We would like to thank Jean-Luc Ayral, CEO of the FORCE-A company, for the courtesy loan of a Dualex Flav.

\section{REFERENCES}

AGATI, G.; CEROVIC, Z.G.; DALlA MARTA, A.; DI STEFANO, V.; PINELLI, P.; TRAVERSI, M.L.; ORLANDINI, S. Opticallyassessed preformed flavonoids and susceptibility of grapevine to Plasmopara viticola under different light regimes. Functional Plant Biology, v.35, p.77-84, 2008.

AGRIOS, G.N. Plant pathology. San Diego: Academic Press, 1998. $635 \mathrm{p}$.

CARTELAT, A.; CEROVIC, Z.G.; GOULAS, Y.; MEYER, S.; LELARGE, C.; PRIOUL, J.L.; JEUFFROY, M.H.; GATE, P.; AGATI, G.; MOYA, I. Optically assessed contents of leaf polyphenolics and chlorophyll as indicators of nitrogen deficiency in wheat (Triticum aestivum L.). Field Crops Research, v.91, p.35-49, 2005.

BARTHOD, S.; CEROVIC, Z.G.; EPRON, D. Can dual chlorophyll fluorescenceexcitation be used to asses the variation in the content of UV absorbing phenolic compounds in leaves of temperate tree species along an irradiance gradient? Journal of Experimental Botany, v.58, p.1753-1760, 2007.

BONOMELLI, A.; MERCIER, L.; FRANCHEL, K.; BAILLIEUL, F.; BENIZRI, E.; MAURO, M.C. Response of grapevine defenses to UV-C exposure. American Journal of Enology and Viticulture, v.55, p.51-59, 2004.

DAI, G.H.; ANDARY, C.; MONDOLOT-COSSON, L.; BOUBALS, D. Histochemical responses of leaves of in vitro plantlests of Vitis spp. to infection with Plasmopara viticola. Phytopathology, v.46, p.177-188, 1995a. 
DAI, G.H.; ANDARY, C.; MONDOLOT-COSSON, L.; BOUBALS, D. Histochemical studies on the interaction between three species of grapevine, Vitis vinifera, V. rupestris and V. rotundifolia and the downy mildew fungus, Plasmopara viticola. Physiological and Molecular Plant Pathology, v.46, p.177-188, 1995b.

DIXON, R.A.; PAIVA, N.L. Stress-induced phenylpropanoid metabolism. Plant Cell, v.7, p.1085-1097, 1995.

ENSMINGER, P.A. Control development in plants and fungi by far-UV radiation. Physiologia Plantarum, v.88, p.501-508, 1993.

GEETHA, N.P.; AMRUTHESH, K.N.; SHARATHCHANDRA, R.G.; SHETTY, H.S. Resistance to downy mildew in pearl millet is associated with increased phenylalanine ammonia lyase activity. Functional Plant Biology, v.32, p.267-275, 2005.

GOULAS, Y.; CEROVIC, Z.G.; CARTELAT, A.; MOYA, I. Dualex: A new instrument for field measurements of epidermal UVabsorbance by chlorophyll fluorescence. Applied Optics, v.43, p.4488-4496, 2004.

HAMMERSCHMIDT, R. Phytoalexins: what have we learned after 60 years? Annual Review of Phytopathology, v.37, p.285306, 1999.

JERSCH, S.; SCHERER, C.; HUTH, G.; SCHLÖSSER, E. Proanthocyanidis as a basis for quiescence of Botrytis cinerea in immature strawberry fruits. Journal of Plant Diseases and Protection, v.96, p.365-378, 1989.

KOLB, C.; KÄSER, M.A.; KOPECKY, J.; ZOTZ, G.; REIDERER, M.; PFÜNDEL, E.E. Effects of natural intensities of visible and ultraviolet radiation on epidermal ultraviolet screening and photosynthesis in grape leaves. Plant Physiology, v.127, p.863-875, 2001.

KOLB, C.A.; PFÜNDEL, E.E. Origins of non-linear and dissimilar relationships between epidermal UV absorbance and UV absorbance of extracted phenolics in leaves of grapevine and barley. Plant, Cell \& Environment, v.25, p.580-590, 2005.

KORTEKAMP, A. Expression analysis of defence-related genes in grapevine leaves after inoculation with a host and a non-host pathogen. Plant Physiology and Biochemistry, v.44, p.58$67,2006$.
MATTA, A. Fondamenti di patologia vegetale. Bologna: Pàtron Editore, 1996. 496p.

NIRANJAN RAJ, S.; SAROSH, B.R.; SHETTY, H.S. Induction and accumulation of polyphenol oxidase activities as implicated in development of resistance against pearl millet downy mildew disease. Functional Plant Biology, v.33, p.563-571, 2006.

ORLANDINI, S. Agrometeorological models for crop protection. In: INTERNATIONAL SYMPOSIUM IN APPLIED AGROMETEOROLOGY AND AGROCLIMATOLOGY, Volos, 1996. Proceedings. Volos, 1998. p.213-222.

PENNYPACKER, B.W. Differential impact of carbon assimilation on the expression of quantitative and qualitative resistance in alfalfa (Medicago sativa). Physiological and Molecular Plant Pathology, v.57, p.87-93, 2000.

PETEZ, R.; PONG, V. Differing biochemical and histological studies of two grape cultivars in the view of their respective susceptibility and resistance to Botrytis cinerea. In K. Verhoeff, N.E. Maltrakis \& B. Williamson. In: Recent Advances in Botrytis Research. Wageningen: Pudoc Scientific, 1992. p.93-98.

ROBERTS, M.R.; PAUL, N.D. Seduced by the dark side: integrating molecular and ecological perspectives on the influence of light on plant defence against pests and pathogens. The New Phytologist, v.170, p.677-699, 2006.

ROZEMA, J.; STAIJ, J. van de; BJÖRN, L.O.; CALDWELL, M. UV-B as an environmental factor in plant life: stress and regulation. Trends in Ecology and Evolution, v.12, p.22-28, 1997.

SHAFIA, A.; SUTTON, J.C.; YU, H.; FLETCHER, R.A. Influence of preinoculation light intensity on development and interactions of Botrytis cinerea and Clonostachys rosea in tomato leaves. Canadian Journal of Plant Pathology, v.23, p.346-357, 2001.

Received November 01, 2007

Accepted June 16, 2008 